УДК 811.111:371.3 (045)

\title{
ВИЗНАЧЕННЯ КРИТЕРІЇВ РІВНЯ СФОРМОВАНОСТІ ПЕДАГОГІЧНОӤ КОМПЕТЕНТНОСТІ МАЙБУТНЬОГО ДИСПЕТЧЕРА-ІНСТРУКТОРА УПРАВЛІННЯ ПОВІТРЯНОГО РУХУ
}

\author{
Немлій Л. С. \\ nemliy_mila@ukr.net \\ Національний авіаційний університет \\ Дата надходження 26.02.2018. Рекомендовано до друку 30.04.2018.
}

\begin{abstract}
Анотація. Стаття грунтується на результатах аналізу наукових робіт, присвячених формуванню у інженерівпедагогів педагогічної компетентності. Проаналізовано наявні наукові концепції щодо визначення критеріїв рівня iї сформованості. Грунтуючись на результатах проведеного аналізу, ми визначили критерії рівня сформованості педагогічної компетентності майбутнього диспетчера-інструктора управління повітряним рухом. Наголошується на необхідності здійснення оптимального вимірювання рівня сформованості структурних компонентів педагогічної компетентності диспетчера-інструктора управління повітряним рухом для забезпечення кількісного та якісного оцінювання рівня іiї сформованості загалом. Критерії оцінювання рівня сформованості педагогічної компетентності майбутніх диспетчерів-інструкторів управління повітряним рухом обирались нами відповідно до структурних компонентів педагогічної компетентності, кожен з яких має змістове наповнення, що включає знання, вміння і навички та якості, які мають бути належним чином сформовані в освітньому процесі.

Ключові слова: критерії рівня сформованості педагогічної компетентності, диспетчер-інструктор управління повітряним рухом, педагогічна компетентність.
\end{abstract}

Немлий Л. С. Национальный авиационный университет

Определение критериев уровня формирования педагогической компетентности будущего диспетчераинструктора управления воздушным движением

Аннотация. Статья основывается на результатах анализа научных работ, посвященных формированию у инженеров-педагогов педагогической компетентности. Проанализированы существующие научные концепции по определению критериев уровня её сформированости. Основываясь на результатах проведенного анализа, мы определили уровни формирования педагогической компетентности будущего диспетчера-инструктора управления воздушным движением. Подчеркивается необходимость осуществления оценивания уровня формирования педагогической компетентности диспетчера-инструктора управления воздушным движением для обеспечения количественного и качественного оценивания уровня формирования педагогической компетентности будущих диспетчеров-инструкторов управления воздушным движением в целом. Критерии уровня формирования педагогической компетентности будущих диспетчеров-инструкторов управления воздушным движением отбирались нами соответственно структурным компонентам педагогической компетентности. Каждый из критериев конкретного уровня имеет содержательное наполнение, включающее знания, умения и навыки и качества, которые должны быть должным образом сформированы в учебном процессе.

Ключевые слова: критерии уровня формирования педагогической компетентности, диспетчер-инструктор управления воздушным движением, педагогическая компетентность

Nemlii L. National Aviation University

Specification of prospective air traffic controller-instructors' pedagogical competence formation criteria Abstract. Introduction. The article presents the results of scientists' research of the pedagogical competence formation of prospective air traffic controller instructor. Based on the reached results the determination of pedagogical competence formation prospective air traffic controller-instructor criteria has been defined. Purposes. To determine the criteria of the prospective air traffic controller-instructor's pedagogical competence formation; to modify and differentiate the peculiarities of each criteria level of the prospective air traffic controllerinstructor's pedagogical competence formation. Methods. Researches examine the pedagogical competence formation of engineer educators; interpret substantial scientific concepts of criteria determination of pedagogical 
competence formation of prospective air traffic controller-instructors. Results. This study revealed that specification the criteria for pedagogical competence formation is necessary for addictive estimation of pedagogical competence of prospective air traffic controller-instructors to provide high level training process for air traffic controller-trainee. The scientists' researches devoted to pedagogical competence formation and the substantial scientific concepts concerning specification of the criterion of its formation have been analyzed and based on the results of the analysis we have modified the levels of the pedagogical competence formation of the prospective air traffic controller-instructor. The measurement of pedagogical competence structural components of the ATCinstructor is provided through quantitative and qualitative assessment of pedagogical competence formation of prospective ATC-instructors completely. The criteria for assessing the level of the pedagogical competence formation of the prospective ATC-instructors have been chosen in accordance with the structural components of pedagogical competence, each of them has content, which includes knowledge, skills and abilities, which should be properly formed in the educational process. Due to the content of each structural component of pedagogical competence, we have distinguished its qualitative characteristics, which are used to evaluate the level of a particular component formation. Conclusion. In conclusion it is worth mentioning that criteria corresponds to the pedagogical competence structural components, therefore, in our research, the evaluation criteria regarding six competency components - motivating, communicating, technological, managerial, personal and reflexive - have been established and the descriptors of pedagogical competence of ATCOI at 4 levels (extended, operational, basic, below basic) have been identified. In order to provide the scientific test of the theoretical part of the experience we organize the experimental research. It shows the positive dynamic growth of extended and operational level in pedagogical competence formation.

Key words: criteria of pedagogucal competence formation, air traffic controller-instructor, pedagogical competence.

Постановка проблеми. Унаслідок здійсненого нами аналізу наукових підходів до визначення критеріїв рівня сформованості педагогічної компетентності майбутнього диспетчера-інструктора управління повітряним рухом (УПР) виявлено необхідність формулювання якісних характеристик кожного критерію за всіма рівнями, що передають точно в описовій формі конкретний рівень сформованості педагогічної компетентності даного фахівця. Визначені критерії й рівні слугуватимуть інструментом кількісного та якісного оцінювання рівня сформованості педагогічної компетентності майбутніх диспетчерів-інструкторів УПР, що, в свою чергу, засвідчить рівень їхньої готовності до організації педагогічного процесу, а саме стажування диспетчерів-стажерів УПР на робочому місці.

Аналіз останніх досліджень і публікацій. Аналіз наукових праць Баркасі В.В., Бігич О.Б., Иванової Т.В., Курило В.С., Маркової А.К. та інших показав, що сукупність визначених критеріїв забезпечує оптимальне вимірювання рівня сформованості структурних компонентів педагогічної компетентності диспетчера-інструктора УПР та дає можливість здійснити кількісне та якісне оцінювання рівня сформованості педагогічної компетентності майбутніх диспетчерівінструкторів УПР загалом.

Мета статті - проаналізувати наукову літературу щодо визначення критеріїв рівня сформованості педагогічної компетентності та визначити критерії рівня сформованості у майбутнього диспетчера-інструктора УПР педагогічної компетентності, сформулювати їхні якісні характеристики та описати їх за рівнями.

Рівень сформованості педагогічної компетентності майбутнього диспетчера-інструктора УПР залежить від рівня сформованості ії структурних компонентів. Для проведення достовірного оцінювання педагогічної компетентності майбутнього диспетчера-інструктора УПР нам потрібно було визначити критерії, сформулювати їхні якісні характеристики та описати їх за рівнями. Критерії, рівні та якісні характеристики мають найточніше охарактеризувати знання майбутнього диспетчера-інструктора УПР та передати в описовій формі рівень сформованості його педагогічної компетентності. При визначенні рівня сформованості компонента за відповідними критеріями і показниками оцінювання педагогічної компетентності враховуємо досвід різних науковців (Бігич, 2006; Маркова, 1995; Никулина, 1989). 
Основні результати дослідження. Визначення меж між рівнями сформованості педагогічної компетентності - це процедура умовна, однак вона дає можливість оцінити якість її сформованості до відповідних діапазонів за певними критеріями. Виокремлення рівнів сформованості компонентів дає змогу розпізнати ступінь їх сформованості, виявити низько сформовані та високо сформовані, визначитися з необхідністю внесення корективів до подальшого способу формування та вибором засобів і методів, за допомогою яких можна впливати на їх позитивне зростання (Баркасі, 2004).

Дослідження тлумачення поняття “критерій” та конкретизація його змісту дає можливість вирішити поставлену мету. Відомо, що критерій - це ознака, на основі якої здійснюється оцінювання, ступінь розвитку тієї чи іншої якості. Критерій - це засіб визначення, норма, мірило, мірка, яка використовується для оцінювання предмета чи явища (Білодід, 1977).

В.С. Курило (1999) зазначає, що у педагогіці під поняттям “критерій” розуміють ознаку, що відображає суттєві якісні характеристики. Значення найбільш загального поняття “критерій” це важлива й визначальна ознака, яка характеризує різні якісні аспекти явища, його сутність. Як відомо, критерій є ознакою, за якою відбувається оцінювання або класифікування чого-небудь (Баркасі, 2004). Це визначення обираємо за основу з-поміж інших визначень терміна.

Отже, критерії педагогічної компетентності диспетчера-інструктора УПР мають відображати різницю між рівнями, містити розпізнавальні ознаки, оцінювати ступінь сформованості

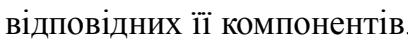

Аналіз праць показав, що зазвичай критерії оцінювання різних компонентів педагогічної компетентності фахівців різного профілю визначаються дослідниками по-різному. Одні вчені стверджують, що об'єктивними критеріями можуть бути лише показники приладів, а оцінювати в педагогіці можна лише суб'єктивно. Суб'єктивне оцінювання здійснює експерт або викладач на основі роздумів, висновків, оцінок (Иванова, 1983). Інші дослідники визначають критерії на основі конкретних компетенцій, які деталізують той чи інший компонент педагогічної компетентності (Баркасі, 2004; Чистовська, 2006).

Критерії педагогічної компетентності мають відображати ії суттєві характеристики за допомогою певних ознак і точних показників і бути достатніми для визначення рівня iï сформованості як результату освітнього процесу (Баркасі, 2004). Через певні змістові показники виявляється кожний із визначених критеріїв у реальній педагогічній дійсності. Показник це кількісна характеристика явищ і процесів, які дають змогу зробити висновок про їхній стан у динаміці (Чистовська, 2006).

Отже, щоб бути достатніми для оцінювання рівня сформованості педагогічної компетентності майбутнього диспетчера-інструктора УПР, критерії мають відповідати структурним компонентам педагогічної компетентності, тому критерії педагогічної компетентності мають назву, ідентичну структурним компонентам педагогічної компетентності: мотиваційний, комунікативний, технологічний, менеджерський, особистісний та рефлективний.

Відповідно, рівень сформованості педагогічної компетентності майбутнього диспетчераінструктора УПР залежить від рівня сформованості кожного окремого структурного компонента педагогічної компетентності.

До змісту кожного структурного компонента педагогічної компетентності майбутнього диспетчера-інструктора УПР входять конкретні для кожного знання, навички й уміння та якісні характеристики, тому рівень сформованості педагогічної компетентності залежить від рівня їх сформованості.

Визначення рівня сформованості кожного структурного компонента педагогічної компетентності ми здійснюємо за допомогою експертних оцінок, тестування, анкетування та самооцінювання. 
Виникає проблема, пов'язана з вибором науково обгрунтованих показників і рівнів, які найбільш об'єктивно та змістовно охарактеризують поняття сформованості педагогічної компетентності майбутнього диспетчера-інструктора УПР. Під показниками розуміємо якісні характеристики, що відповідають певному рівню сформованості педагогічної компетентності.

Крім того, визначити ступінь вимірюваності компонентів, як стверджує О. П. Петращук (2003), можливо через вимірювання не самих компонентів, а лише вмінь або здатності виконувати конкретні операції, дії, характерні для тих компонентів.

Оскільки критерії оцінювання рівня сформованості педагогічної компетентності майбутніх диспетчерів-інструкторів УПР обиралися нами відповідно до структурних компонентів педагогічної компетентності, кожен з них має змістове наповнення (табл. 1), що включає знання, навички і вміння та якості, які мають бути належним чином сформовані в освітньому процесі. Відповідно до виокремленого змістового наповнення кожного структурного компонента педагогічної компетентності формулюємо його якісні характеристики, завдяки яким й оцінюємо рівень сформованості певного компонента.

Отже, розглядаючи структуру педагогічної компетентності майбутніх диспетчерівінструкторів УПР як єдність мотиваційного, технологічного (методологічного), комунікативного, особистісного, менеджерського, рефлективного компонентів, ми вважаємо за доцільне критеріями iii сформованості визначити такі:

$\begin{array}{ll}\checkmark & \text { мотиваційний; } \\ \checkmark & \text { технологічний; } \\ \checkmark & \text { комунікативний; } \\ \checkmark & \text { особистісний; } \\ \checkmark & \text { менеджерський; } \\ \checkmark & \text { рефлективний. }\end{array}$

Зміст структурних компонентів педагогічної компетентності

Таблиия 1 диспетчера-інструктора УПР

\begin{tabular}{|c|c|c|}
\hline $\begin{array}{l}\text { Мотиваційний: } \\
\text { інтерес до організації } \\
\text { педагогічної діяльності; } \\
\text { активність під час } \\
\text { освітнього процесу; стійкі } \\
\text { мотиви і цілі до } \\
\text { педагогічної діяльності }\end{array}$ & $\begin{array}{l}\text { Комунікативний: } \\
\text { уміння спілкуватися, } \\
\text { уміння встановлювати } \\
\text { міжособистісні зв'язки; } \\
\text { уміння погоджувати свої } \\
\text { дії з діями стажистів; } \\
\text { уміння обирати } \\
\text { оптимальний стиль } \\
\text { спілкування у навчальних } \\
\text { ситуаціях }\end{array}$ & $\begin{array}{l}\text { Технологічний: знання про } \\
\text { педагогічну діяльність; вміння } \\
\text { їх застосовувати при вирішенні } \\
\text { педагогічної ситуації; вміння } \\
\text { використовувати ефективні } \\
\text { методи та принципи в } \\
\text { організації освітнього процесу, } \\
\text { уміння передавати власні } \\
\text { професійні знання стажистам }\end{array}$ \\
\hline $\begin{array}{l}\text { Менеджерський: } \\
\text { вміння управляти освітнім } \\
\text { процесом теоретичної, } \\
\text { практичної та тренажерної } \\
\text { підготовки диспетчера- } \\
\text { стажиста УПР }\end{array}$ & $\begin{array}{l}\text { Особистісний: } \\
\text { особистісні якості: } \\
\text { творчість; критичність, } \\
\text { самостійність, } \\
\text { толерантність, емпатія, } \\
\text { відчуття балансу } \\
\text { міжособистісних стосунків }\end{array}$ & $\begin{array}{l}\text { Рефлективний: уміння давати } \\
\text { самооцінку, розуміти значення } \\
\text { власних знань, навичок та вмінь } \\
\text { щодо організації освітнього } \\
\text { процесу, уміння аналізувати та } \\
\text { коригувати власну педагогічну } \\
\text { діяльність, прагнення до } \\
\text { самовдосконалення }\end{array}$ \\
\hline
\end{tabular}

Якісні характеристики критеріїв оцінювання сформованості педагогічної компетентності майбутнього диспетчера-інструктора УПР розроблені на основі змісту ії компонентів та включають знання, навички, вміння та особистісні якості (Микитенко, 2011): 
$\checkmark$ мотиваційний критерій: стійкі мотиви і цілі до педагогічної діяльності, ступінь активності під час освітнього процесу; наявність стійких мотивів і цілеспрямованості до педагогічної діяльності;

$\checkmark$ комунікативний критерій: уміння спілкуватися, встановлювати міжособистісні зв'язки, погоджувати свої дії з діями стажистів, обирати оптимальний стиль спілкування у навчальних ситуаціях, опановувати засоби вербального і невербального спілкування;

$\checkmark$ технологічний критерій: знання про педагогічну діяльність, уміння їх застосовувати при вирішенні педагогічних ситуацій, вміння використовувати ефективні методи та принципи в освітньому процесі, уміння передавати власні професійні знання стажистам;

$\checkmark$ менеджерський критерій: уміння управляти освітнім процесом теоретичної, практичної та тренажерної підготовки диспетчера-стажиста УПР і самим собою;

$\checkmark$ особистісний критерій: встановлюються особистісні якості - творчість, критичність, самостійність, толерантність, емпатія, відчуття балансу міжособистісних стосунків;

$\checkmark$ рефлективний критерій: уміння давати самооцінку, розуміти значення власних знань, умінь та навичок щодо організації освітнього процесу, вміння аналізувати та коригувати власну педагогічну діяльність, прагнення до самовдосконалення.

На підставі визначених критеріїв за властивими ознаками відповідних якісних характеристик визначаємо рівень сформованості педагогічної компетентності майбутнього диспетчераінструктора УПР. Фактори, що впливають на визначення рівнів сформованості педагогічної компетентності, - це їхня різноманітність. У педагогіці представлено різні погляди щодо їх визначень.

В.Н. Введенський (2003) виділяє три рівні: вузький рівень, який передбачає сформованість необхідної операційної компетентності; достатній рівень, який передбачає сформованість операційних і ключових компетентностей; широкий рівень, який передбачає сформованість операційних, ключових і базових компетентностей.

А.К. Маркова (1995) виділяє три рівні сформованості педагогічної компетентності: високий, середній, низький.

В.П. Беспалько (1989) визначає чотири рівні педагогічної компетентності, якісні характеристики яких вказують на межу відповідно до рівня засвоєння знань, сформованості навичок та розвитку вмінь як низький, базовий, достатній та високий.

За основу визначення рівня сформованості педагогічної компетентності майбутнього диспетчера-інструктора УПР ми обрали рівні засвоєння знань слідом за В.П. Беспальком (Беспалько, 1989) та адаптували їх для визначення рівня сформованості знань, навичок, умінь та якісних характеристик відповідно до кожного компонента педагогічної компетентності майбутнього диспетчера-інструктора УПР.

Для забезпечення оцінювання сформованості педагогічної компетентності майбутнього диспетчера-інструктора УПР, слідом за вищезгаданим дослідником, ми виділяємо 4 рівні сформованості компонентів педагогічної компетентності за критеріями:

$$
\begin{aligned}
& \text { 1-ий рівень - низький; } \\
& \text { 2-ий рівень - базовий; } \\
& \text { 3-ий рівень - достатній; } \\
& \text { 4-ий рівень - високий. }
\end{aligned}
$$

Розуміємо, що зміст рівня сформованості знань, навичок, умінь та якостей, який відповідає кожному компоненту за критерієм педагогічної компетентності майбутнього диспетчераінструктора УПР, виражається по-різному. Спостерігається тенденція щодо глибини засвоєння знань студентом за різними критеріями:

$\checkmark$ низький рівень - поверхневе засвоєння знань;

$\checkmark$ базовий рівень - знання мають епізодичний характер; 
$\checkmark$ достатній - знання, засвоєні до рівня вмінь;

$\checkmark$ високий - володіння знаннями на креативному рівні.

Подання змісту різних рівнів критеріїв педагогічної компетентності майбутнього диспетчераінструктора УПР у загальному вигляді здійснюємо за допомогою якісних характеристик у такий спосіб.

Низький рівень сформованості педагогічної компетентності є характерним для студента, в якого відсутня зацікавленість у педагогічній діяльності, відсутні знання про особливості педагогічної діяльності; який невдало обирає стиль спілкування у навчальній ситуації; нездатний управляти освітнім процесом; не володіє елементарними навичками культури та має слабко сформовані професійно значущі якості та здібності; не вміє або не виявляє бажання критично аналізувати власну діяльність, не володіє вміннями самоконтролю і корекції власної діяльності з неадекватною самооцінкою власного рівня сформованості педагогічної компетентності.

Базовий рівень сформованості педагогічної компетентності є характерним для майбутнього диспетчера-інструктора УПР, якому притаманна ситуаційна зацікавленість у педагогічній діяльності, який має поверхневі знання про специфіку педагогічної діяльності, частково проявляє вміння управляти освітнім процесом; не повною мірою володіє особистісними якостями та здібностями, не завжди адекватно оцінює власну діяльність; невпевнений щодо педагогічної діяльності через поверхові знання.

Достатній рівень сформованості педагогічної компетентності є характерним для майбутнього диспетчера-інструктора УПР, який має знання про специфіку педагогічної діяльності; певною мірою може встановлювати міжособистісні зв'язки, обирати оптимальний стиль спілкування в навчальних ситуаціях; загалом уміє управляти освітнім процесом; переважно адекватно оцінює власний рівень педагогічної компетентності.

Високий рівень сформованості педагогічної компетентності диспетчера-інструктора УПР характеризує фахівця, який проявляє професійний інтерес, має стійкі мотиви і цілі до педагогічної діяльності; володіє глибокими знаннями про специфіку такої діяльності, ефективно управляє освітнім процесом, використовуючи методи, форми та засоби навчання; володіє навичками культури та має високосформовані професійно значущі якості й здібності; здатний адекватно оцінювати власний рівень сформованості педагогічної компетентності; вміє аналізувати, оцінювати та вчасно коригувати власну діяльність; постійно прагне до самовдосконалення.

За умови відсутності у майбутнього диспетчера-інструктора УПР тієї чи іншої якісної характеристики за критерієм певного рівня на початок педагогічної підготовки він набуває знань відповідно до критеріїв певного рівня.

Відповідність якісних характеристик за рівнями кожного критерію педагогічної компетентності майбутнього диспетчера-інструктора УПР подаємо у табл. 2:

1) мотиваційний критерій:

$\checkmark$ низький рівень сформованості мотиваційного компонента характеризується відсутністю у майбутнього диспетчера-інструктора УПР зацікавленості в педагогічній діяльності, пасивним ставленням до організації освітнього процесу щодо педагогічної підготовки;

$\checkmark$ базовий рівень сформованості мотиваційного компонента характеризує студента, якому притаманна ситуаційна зацікавленість у педагогічній діяльності та незначний інтерес до ії підготовки;

$\checkmark$ достатній рівень характеризує студента, який має інтерес до педагогічної діяльності та усвідомлює значущість та необхідність їі підготовки;

$\checkmark$ високий рівень характеризує студента, який має професійний інтерес до педагогічної діяльності, проявляє стійкі мотиви і цілі до її підготовки; 
Немлій Л. С. Визначення критеріїв рівня сформованості педагогічної компетентності майбутнього диспетчера-інструктора управління повітряного руху

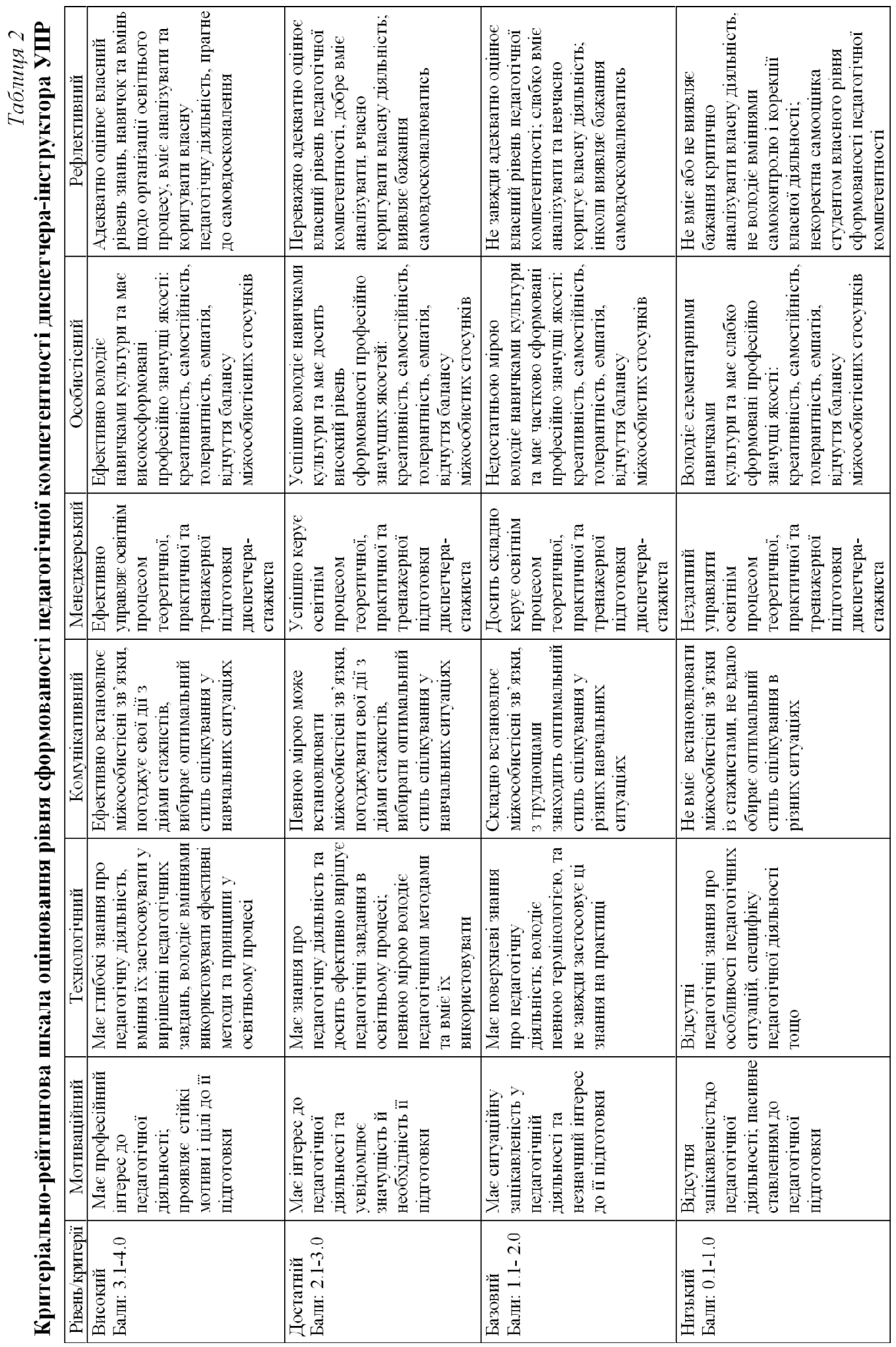


2) технологічний критерій:

$\checkmark$ низький рівень сформованості технологічного компонента характеризує студента, в якого відсутні педагогічні знання про особливості педагогічних ситуацій, специфіку педагогічної діяльності тощо;

$\checkmark$ базовий рівень характеризує студента, який має поверхові знання про специфіку педагогічної діяльності та володіє певною термінологією, хоча не завжди застосовує ці знання на практиці;

$\checkmark$ достатній рівень сформованості технологічного компонента характеризує студента, який має знання про специфіку педагогічної діяльності та досить ефективно вирішує педагогічні завдання в освітньому процесі; певною мірою володіс сучасними педагогічними технологіями та вміє їх використовувати;

$\checkmark$ високий рівень характеризує студента, який має глибокі знання про педагогічну діяльність, вміє їх застосовувати у вирішенні педагогічних завдань, ефективно організовуе освітній процес; досконало володіє сучасними педагогічними технологіями та вміє їх творчо використовувати;

3) комунікативний критерій:

$\checkmark$ низький рівень сформованості комунікативного компонента характеризує студента, який не вміє встановлювати міжособистісні зв'язки із стажистами, невдало обирає оптимальний стиль спілкування у різних навчальних ситуаціях;

$\checkmark$ базовий рівень характеризує студента, який складно встановлює міжособистісні зв'язки, 3 труднощами знаходить оптимальний стиль спілкування у різних навчальних ситуаціях;

$\checkmark$ достатній рівень сформованості комунікативного компонента характеризує студента, який певною мірою може встановлювати міжособистісні зв'язки, погоджувати свої дії з діями стажистів, обирати оптимальний стиль спілкування у навчальних ситуаціях;

$\checkmark$ високий рівень характеризує студента, який ефективно встановлює міжособистісні зв' язки, погоджує свої дії з діями стажистів, обирає оптимальний стиль спілкування у навчальних ситуаціях;

4) менеджерський критерій:

$\checkmark$ низький рівень сформованості менеджерського компонента характеризує студента, який не здатний управляти освітнім процесом теоретичної, практичної та тренажерної підготовки диспетчера-стажиста УПР під час навчальної діяльності;

$\checkmark$ базовий рівень характеризує студента, який досить складно управляє освітнім процесом теоретичної, практичної та тренажерної підготовки диспетчера-стажиста УПР;

$\checkmark$ достатній рівень характеризує студента, який успішно управляє освітнім процесом теоретичної, практичної та тренажерної підготовки диспетчера-стажистами УПР;

$\checkmark$ високий рівень характеризує студента, який ефективно управляє освітнім процесом теоретичної, практичної та тренажерної підготовки диспетчера-стажиста УПР і самим собою;

5) особистісний критерій:

$\checkmark$ низький рівень сформованості особистісного компонента характеризує студента, який володіє елементарними навичками культури та має слабко сформовані професійно значущі якості й здібності;

$\checkmark$ базовий рівень характеризує студента, який недостатньою мірою володіє навичками культури та має частково сформовані професійно значущі якості й здібності;

$\checkmark$ достатній рівень сформованості особистісного компонента характеризує студента, який успішно володіє навичками культури та має достатній рівень сформованості професійно значущих якостей і здібностей;

$\checkmark$ високий рівень сформованості особистісного компонента характеризує студента, який ефективно володіє навичками культури та має високосформовані професійно значущі якості й здібності, такі як толерантність, критичність, самостійність; емпатія, відчуття балансу міжособистісних стосунків; 
6) рефлективний критерій:

$\checkmark$ низький рівень сформованості рефлективного компонента характеризує студента, який не вміє або не виявляє бажання критично аналізувати власну діяльність, не володіє вміннями самоконтролю і не коригує власну педагогічну діяльність; самооцінка студентом власного рівня сформованості педагогічної компетентності некоректна;

$\checkmark$ базовий рівень характеризує студента, який не завжди адекватно оцінює власний рівень педагогічної компетентності, погано вміє аналізувати, оцінювати та невчасно коригує власну діяльність; епізодично виявляє бажання самовдосконалюватись;

$\checkmark$ достатній рівень має студент, який переважно адекватно оцінює власний рівень педагогічної компетентності, вміє добре аналізувати, оцінювати, вчасно коригує власну діяльність; має бажання самовдосконалюватись;

$\checkmark$ високий рівень характеризує студента, який здатний давати самооцінку, розуміти значення власних знань, навичок та вмінь щодо організації навчального процесу, вміє аналізувати, оцінювати та вчасно коригувати власну діяльність; постійно прагне до самовдосконалення.

Висновки і перспективи подальших розвідок. Отже, сукупність визначених критеріїв забезпечить оптимальне вимірювання рівня сформованості структурних компонентів педагогічної компетентності диспетчера-інструктора УПР і уможливить здійснення кількісного та якісного оцінювання рівня сформованості педагогічної компетентності майбутніх диспетчерів-інструкторів УПР загалом.

\section{ЛІТЕРАТУРА}

Баркасі, В.В. (2004). Формування професійної компетентності в майбутніх вчителів іноземних мов (Кандидатська дисертація). Південноукраїнський державний педагогічний університет імені К. Д. Ушинського, Одеса, Україна.

Беспалько, В.П. (1989). Слагаемые педагогической технологии. Москва, СССР: Педагогика. Бігич, О.Б. (2006). Теорія і практика формування методичної компетениії вчителя іноземної мови початкової школи. Київ, Україна: Ленвіт.

Введенский, В. Н. (2003). Моделирование профессиональной компетентности педагога. Педагогика, 10, 51-55.

Иванова, Т. В. (1983). Особенности развития психологической готовности студентов к педагогической деятельности (Автореферат кандидатской диссертации). Московский государственный педагогический институт, Москва, СССР.

Курило, В. С. (1999). Моделювання системи критеріїв оцінки розвитку освіти в регіоні. Педагогіка і психологія, 2, 35-39.

Маркова, А.К. (1995). Психологические критерии и ступени профессионализма учителя. Педагогика, 6, 27-31.

Микитенко, Н. О. (2011). Технологія формування іншомовної компетентності майбутніх фахівиів природничого профілю [монографія]. Тернопіль, Україна: ТНПУ.

Никулина, А. С. (1989). Четыре ступени компетентности. Профессионально-техническое образование, 4, 27-29.

Петращук, О. П. (2003). Як зробити тест з іноземної мови: практичні поради. Іноземні мови у навчальних закладах, 4, 48-47.

Білодід, І. К. (Гол. ред.). (1977). Словник украӥнської мови [в 11 т.]. Т. 8. Київ: Наук. думка.

Чистовська, І. П. (2006). Формування педагогічної компетентності майбутніх магістрів військового управління (Кандидатська дисертація). Національна академія оборони України, Київ, Україна. 


\section{REFERENCES}

Barkasi, V.V. (2004). Formuvannia profesijnoi kompetentnosti v majbutnikh vchyteliv inozemnykh mov (Kandydats'ka dysertatsiia). Pivdennoukrains'kyj derzhavnyj pedahohichnyj universytet imeni K. D. Ushyns'koho, Odesa, Ukraina.

Bespal'ko, V.P. (1989). Slagaemye pedagogicheskoj tehnologii. Moskva, SSSR: Pedagogika.

Bihych, O.B. (2006). Teoriia i praktyka formuvannia metodychnoi kompetentsii vchytelia inozemnoi movy pochatkovoi shkoly. Kyiv, Ukraina: Lenvit.

Vvedenskij, V. N. (2003). Modelirovanie professional'noj kompetentnosti pedagoga. Pedagogika, $10,51-55$.

Ivanova, T. V. (1983). Osobennosti razvitija psihologicheskoj gotovnosti studentov k pedagogicheskoj dejatel'nosti (Avtoreferat kandidatskoj dissertacii). Moskovskij gosudarstvennyj pedagogicheskij institut, Moskva, SSSR.

Kurylo, V. S. (1999). Modeliuvannia systemy kryteriiv otsinky rozvytku osvity v rehioni. Pedahohika i psykholohiia, 2, 35-39.

Markova, A.K. (1995). Psihologicheskie kriterii i stupeni professionalizma uchitelja. Pedagogika, 6, 27-31.

Mykytenko, N. O. (2011). Tekhnolohiia formuvannia inshomovnoi kompetentnosti majbutnikh fakhivtsiv pryrodnychoho profiliu. [monohrafiia]. Ternopil', Ukraina: TNPU.

Nikulina, A. S. (1989). Chetyre stupeni kompetentnosti. Professional'no-tehnicheskoe obrazovanie, 4, 27-29.

Petraschuk, O. P. (2003). Yak zrobyty test z inozemnoi movy: praktychni porady. Inozemni movy u navchal'nykh zakladakh, 4, 48-47.

Bilodid, I. K. (Hol. red.). (1977). Slovnyk ukrains'koi movy [v 11 t.]. T. 8. Kyiv, Ukraina: Nauk. dumka.

Chystovs'ka, I. P. (2006). Formuvannia pedahohichnoi kompetentnosti majbutnikh mahistriv vijs'kovoho upravlinnia (Kandydats'ka dysertatsiia). Natsional'na akademiia oborony Ukrainy, Kyiv, Ukraina. 